\title{
The Management of Waste from Electrical and Electronic Equipment (WEEE) in Bangkok, Thailand
}

\author{
Sirada Pookkasorn ${ }^{1}$, Alice Sharp ${ }^{2}$
}

\begin{abstract}
Because of the rapid increasing and improving of new technologies in electrical and electronic equipment industry, the consumption of home appliances (e.g. televisions, refrigerators, washing machines) and information technology equipment (e.g. personal computers, mobile phones) has sharply increased. Therefore, huge amount of waste electrical and electronic equipment (WEEE), known as E-waste, becomes one of the rapidly growing pollution problems. Not only in terms of quality but E-waste contains hazardous substances that can release to the environment and threaten human health if using unsafe recycling and disposal practices. Thailand is one of the countries that have been facing E-waste problems both from domestic generation and illegal importation. The important factor of E-waste problems in Thailand is "the informal sector" who plays a major role in Thai E-waste disposal by using unsafe dismantling and recycling methods to get and recovery costly components in E-waste.

This study aims to focus on the current situation of E-waste in Bangkok area by the informal sector including field survey study about their activities and interview their opinion to the "Draft Act of the Management of Waste electrical and Electronic Equipment". The samples are E-waste collectors and recyclers in Wat Suan Kaew Foundation and Soi Sue yai Ootit and secondhand computer shops in Bangkok area. The results from interview can conclude that the majority of samples do not have clearly knowledge about good Ewaste management including effects from E-waste to their health and the environment. And samples do not understand their role in the law lead to disagreement of promulgation. The important keys to solve these problems are to rise public awareness about proper E-waste management and its effects especially to the informal sector. Moreover, to promote people responsibilities in proper E-waste management that set in the law especially promote the alternative role for the informal sector.
\end{abstract}

Keywords - Waste from Electrical and Electronic Equipment, WEEE, E-waste, WEEE management, Electronic waste management

\section{INTRODUCTION}

$\mathrm{W}$ ASTE electrical and electronic equipment (WEEE) or E-waste becomes one of the rapidly growing pollution problems worldwide because the amount of E-waste generation has increasing sharply from many factors such as consumer demand and a high obsolescence rate lead to frequent and unnecessary purchases of electrical and electronic

Sirada Pookkasorn ${ }^{1}$ is with the TAIST-Tokyo Tech Program in Advanced and Sustainable Environmental Engineering, Sirindhorn International Institute of Technology, Thammasat University, Pathumthani 12120, Thailand

Alice Sharp ${ }^{2}$, is with School of Bio-Chemical Engineering and Technology (BCET), Sirindhorn International Institute of Technology, Thammasat University, Pathumthani 12120, Thailand. equipment. [1] The 2012 UN report estimated that by 2017 global E-waste will increase 33\% from 49.7 million to 65.4 million tons per annum [2] whereas WHO estimated that $75 \%$ to $80 \%$ of global E-waste generation are exported to developing countries in Asia and Africa. [3] Thailand is one of developing countries that have been facing E-waste problems due to the lack in technologies, facilities, resources and gaps in E-waste regulations causing illegal importation for E-waste dismantle and recycle purpose. [4-7] Improper or unsafe E-waste recycling by "the informal sector", a major Ewaste stakeholders in Thailand, can distribute toxic substances that contained in E-waste such as heavy metals (e.g. $\mathrm{Cd}, \mathrm{Cu}$ and $\mathrm{Pb}$ ) and persistent organic pollutants (POPs, e.g. dioxin and brominated flame retardants (BFRs)) to soil, air and water around E-waste recycling and landfill sites lead to bioaccumulation, food contamination and widespread ecological exposure resulting in human health impacts. [8-12]

To have environmentally friendly management of E-waste, the Pollution Control Department (PCD) drafted the National Integrated Strategy for the Management of Waste Electrical and Electronic Equipment to cope with E-waste problems in the country which included an action plan and a development of specific law to establish a comprehensive E-waste management in order to have a proper treatment of E-waste and rising public awareness about E-waste issues. [11]

This paper aims to study the current situation of E-waste in Bangkok area by the informal sector including field survey study about their activities and interview their opinion to the Thai E-waste management law.

\section{II.METHODOLOGY}

\section{A. Secondary data collection}

This study reviews about the current situations and E-waste problems in Thailand from previous source such as studies Integrated WEEE management Strategy (2014-2021) and Legislative Drafting on the Management of WEEE and Other Household Hazardous Wastes from Pollution Control Department of Thailand who is in charge of drafting WEEE regulation.

\section{B. Interview and field visit observation}

The study conducted field observation and interview with the informal sector from E-waste peddlers, recyclers and junkshops in Sue yai ootit E-waste community, E-waste scrap dealers and recyclers who attend E-waste auction at Wat suan 
kaew foundation and conducted field observation and interview with 60 secondhand computer shops in Bangkok such as secondhand computer shops in Pantip plaza, IT square Laksi, Foutune Town IT mall, IT Zeer Rangsit and IT zone at Future park Bang Kae and The Mall Bang Kae.

The interview and observation were conducted under 3 main aspects.

1) How they manage with secondhand products, obsolete products and worthless scrap.

2) Do they know about E-waste effect to their health and the environment.

3) What do they think about Thai WEEE management law and strategy.

\section{RESULTS AND DISCUSSION}

\section{A. Current E-waste situation in Thailand}

Waste electrical and electronic equipment (WEEE) or Ewaste is sharply increasing in recent years similarly to global E-waste situation. Pollution Control Department (PCD) estimated that the amount of E-waste generated in 2014 is 376,801 tons and 384,233 tons in 2015 . That forecast was done for only 8 types of household appliances. It is expected that the actual amount of E-waste generation is much bigger than this number and is likely to increase each year. [12,13]

From the study of WEEE assessment in 2012 by PCD and Electrical and Electronics Institute (ThaiEEI), they forecasted the amount of E-waste using Weibull Distribution Model cooperate with Logistic Model which consider about decline stage of electronic equipment market, lifespan of product, field study and product consumption data and found the results as shown in Table1. [14]

TABLE 1

FORECAST OF WASTE ELECTRICAL AND ELECTRONIC EQUIPMENT QUANTITY IN 2012 - 2016

\begin{tabular}{|l|c|c|c|c|c|}
\hline \multirow{2}{*}{ Product } & \multicolumn{5}{|c|}{ Quantity (thousand unit) } \\
\cline { 2 - 6 } & 2012 & 2013 & 2014 & 2015 & 2016 \\
\hline Television & 2,377 & 2,483 & 2,587 & 2,689 & 2,790 \\
\hline $\begin{array}{l}\text { Camera, } \\
\text { VDO } \\
\text { recorder }\end{array}$ & 724 & 785 & 875 & 983 & 1,059 \\
\hline $\begin{array}{l}\text { VCD, DVD } \\
\text { player, } \\
\text { MP3 player }\end{array}$ & 3,253 & 3,380 & 3,476 & 3,537 & 3,571 \\
\hline $\begin{array}{l}\text { Printer, } \\
\text { FAX }\end{array}$ & 1,495 & 1,507 & 1,520 & 1,532 & 1,542 \\
\hline $\begin{array}{l}\text { Telephone, } \\
\text { Mobile } \\
\text { phone }\end{array}$ & 8,524 & 9,146 & 9,750 & 10,337 & 10,907 \\
\hline $\begin{array}{l}\text { Personal } \\
\text { computer, } \\
\text { Notebook }\end{array}$ & 1,789 & 1,999 & 2,210 & 2,421 & 2,630 \\
\hline $\begin{array}{l}\text { Air } \\
\text { conditioner }\end{array}$ & 696 & 717 & 740 & 766 & 796 \\
\hline Refrigerator & 822 & 872 & 922 & 972 & 1,023 \\
\hline
\end{tabular}

The major amount of E-waste are from household which they will collect their equipment and dispose with municipal solid waste. Besides, approximately $50 \%$ of Thai people will sell their obsolete electrical and electronic equipment to the informal sector such as peddlers and junk shops for dismantle and recycle purpose. These behaviors lead to environmental and public health problems because the improper management of E-waste disposal with municipal solid waste and the informal sector using primitive and unsafe recycling methods without any protection, these may cause hazardous substances contaminated to the environment lead to threatening human health. [13] The current situation of E-waste flow is shown in Figure 1.

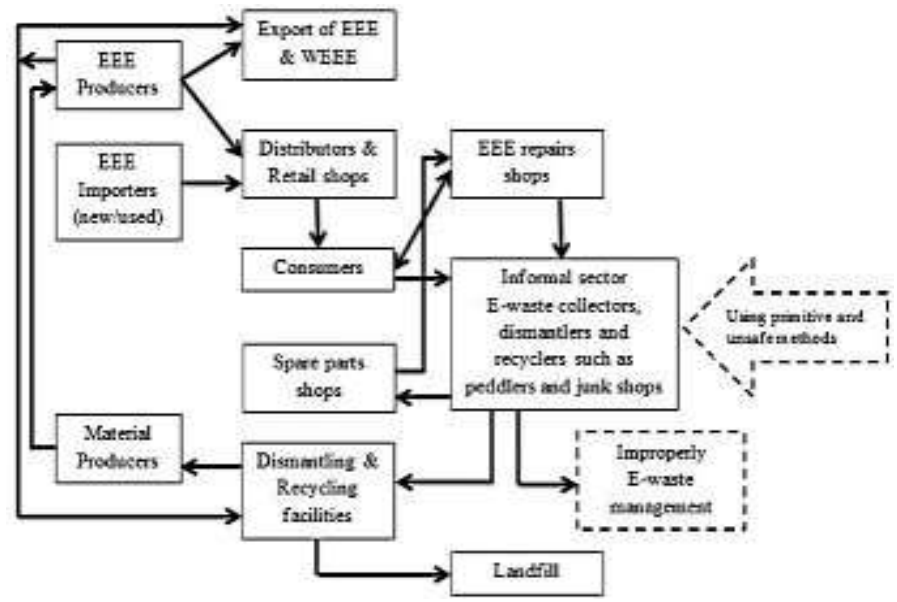

Fig. 1 Cycle of current electrical and electronic equipment in Thailand

Department of Disease Control (DDC) estimated that there are almost 100 electronic waste dismantle and recycle communities in Thailand which commonly located all over the country. These E-waste communities do dismantle and recycle E-waste with primitive method. The important E-waste community in Bangkok is located at "Sue yai ootit E-waste community (Ratchadaphisek 36), Lard Phrao District" [12]

There is a study about heavy metals contamination from Sue yai ootit E-waste communities in soil. The results in Table 2 show that there are obviously high contamination of copper $(\mathrm{Cu})$, lead $(\mathrm{Pb})$ and Zinc $(\mathrm{Zn})$ in E-waste community area. The detected level was higher than control area, Thai soil standard and The Intervention Value (Netherland soil standard). These mean this area need the remediation. While Nickel (Ni), Manganese $(\mathrm{Mn})$ and Chromium $(\mathrm{Cr})$ concentration are higher than control area, these mean this area encountered with heavy metals contamination. These heavy metals can cause health effect such as damage to central and peripheral nervous systems, blood systems, kidney damage and affect children's brain development.

In terms of legislative measure, Thailand does not have clear law, directive or legislation of E-waste management to promote waste avoidance, proper separation and utilization of waste (reuse and recycling). Moreover, E-waste should not be disposed together with municipal waste. It is the duty of local government to collect and dispose and the duty of consumers to separate hazardous waste from municipal waste. All of these reasons cause limitation to control and manage proper E-waste disposal in Thailand which lead to serious problems about uncontrolled processing that caused harmful effects both to the environment and human health by the informal sector who 
play a major role in E-waste disposal.

TABLE 2

HEAVY METALS CONTAMINATION IN SOIL FROM SUE YAI OOTIT E-WASTE COMMUNITY

\begin{tabular}{|c|c|c|c|c|c|c|c|c|c|}
\hline \multirow[t]{2}{*}{ Area } & \multirow{2}{*}{$\begin{array}{l}\text { Research } \\
\text { by }\end{array}$} & \multicolumn{8}{|c|}{$\begin{array}{l}\text { Heavy metal concentration } \\
\text { (mg/kg soil) }\end{array}$} \\
\hline & & $\mathrm{Cu}$ & $\mathrm{Pb}$ & $\mathrm{Zn}$ & $\mathrm{Cd}$ & $\mathrm{Ni}$ & $\mathrm{Mn}$ & $\mathrm{Cr}$ & As \\
\hline $\begin{array}{c}\text { Sue yai } \\
\text { ootit } \\
\text { communi } \\
\text { ty }\end{array}$ & $\begin{array}{l}\text { Damrongs } \\
\text { iri, S., } \\
2014\end{array}$ & $\begin{array}{l}4,8 \\
28\end{array}$ & $\begin{array}{l}1,0 \\
58\end{array}$ & $\begin{array}{l}1,8 \\
47\end{array}$ & $<2$ & 74 & 511 & 88 & - \\
\hline $\begin{array}{l}\text { Bangkok } \\
\text { area's } \\
\text { soil } \\
\end{array}$ & $\begin{array}{l}\text { Damrongs } \\
\text { iri, S., } \\
2014 \\
\end{array}$ & 90 & 67 & 234 & $<2$ & 16 & 374 & 37 & - \\
\hline \multicolumn{2}{|c|}{ Thai soil standard value } & - & 400 & - & 37 & $\begin{array}{l}1,6 \\
00\end{array}$ & $\begin{array}{l}1,8 \\
00\end{array}$ & 300 & 3.9 \\
\hline \multicolumn{2}{|c|}{$\begin{array}{c}\text { The Intervention } \\
\text { Value } \\
\text { (Netherland's standard) }\end{array}$} & 190 & 530 & 720 & 13 & 100 & - & - & 76 \\
\hline
\end{tabular}

To have environmentally friendly management of E-waste, PCD drafted the National Integrated Strategy for the Management of Waste Electrical and Electronic Equipment to cope with E-waste problems in the country which included an action plan and a development of specific law to establish a comprehensive E-waste management in order to have a proper treatment of E-waste and rising public awareness about Ewaste issues. [11]

Draft Act on the Management of Waste electrical and electronic Equipment and Other End-of-Life Product was approved from the cabinet on May, 19 2015. This is specific law to control E-waste management in order to have effective E-waste management system by integrated all stakeholders participation with Extended Producer Responsibility principle (EPR) that producers have responsibilities to pay for E-waste management and improve more environmentally friendly product design by reduce the use of hazardous substances and design easy recycle product to promote sustainable production and consumption. Moreover, this law allows the informal sector to join take-back system by registering with local administrative organization and must operate under the regulation which is good choice for informal sector to operate with good management. However, after this law was sent to The Council of State (Krisdika), it was changed and removed many key topics that may result in lower effective of E-waste management. And now, this law is in a process of improvement and consideration to promulgate.

\section{B. Interview and Field visit observation}

The answers from interviewees can separate into 3 groups of problems concluded as follows.

1) E-waste management problems

- Most of informal E-waste separators run by family base.

- People do dismantle and recycle by using their bare hand and primitive methods without any selfprotection which are not properly methods and lead to hazardous substances emission to the environment and harm to their health.

- After dismantle and separation parts into group such as plastic, copper, electronic board, motor, screen etc., they will sell each group to big E-waste dealers or recyclers for further steps.

- For secondhand computer shops, after they got computers (both from consumers and E-waste auction), they will check working condition and separate good products to sell. For products that fail to work they will dismantle and separate parts for collect as spare parts in order to service as repairing and for the E-waste scarp they will sell to E-waste dealers or recyclers as same as E-waste separators.

- There are huge networks of E-waste trading and recycling behind-the-scenes of small E-waste separators and secondhand shops which cause massive E-waste transfer such as E-waste auction and E-waste trading (some of E-waste trading is illegal and violate the Basel Convention to transport E-waste to other countries such as China, Hong Kong, Japan, Korea and Taiwan).

- For obsolete TVs and computer monitors, there have interesting route that different from other E-waste because the screen and electronic board inside can sell to TV manufacturers for re-built as low-priced products in order to sell up-country and export to neighboring countries such as LAOs and Cambodia.

2) Environment and human health effect problems

- People know only basic information that E-waste is dangerous and may cause cancer. People don't know details about E-waste effect to their health.

- People don't think that separation and dismantle can lead to bad effects of their and public health and adverse to the environment.

- People don't think that touching and breathing in separation process can cause sickness, they think only that "who burn" parts for recycle is more dangerous and be troublemakers.

- People use primitive methods without any protection lead to hazardous substances contaminated in the environment and harm to their health.

- For people who extract precious metals such as gold, silver, copper, lead, nickel and tin from electronic circuit boards, they use chemicals and do open burning for extraction that cause severe environmental contaminated in soil, water and ambient air.

- People dose not realize that their activity lead to widespread social problems.

3) Regulation problems

- People don't have knowledge about E-waste law and regulation. For people who don't know about the law, they don't think that is illegal to do E-waste dismantle and separation.

- Most of E-waste separators and recyclers who know the law are against to E-waste management law because it directly affect to their income.

- Only big E-waste dealers know about the law but they don't understand clearly. 
- Most of E-waste separators and recyclers misunderstand about E-waste management law that will prohibit their business.

- Most of second hand computer shops agree with Ewaste management strategy (EPR) because they understand E-waste problems that cause enormous volume waste and no one take responsibility to control it. Moreover, they don't think that is not effect to their business.

- Some of second hand computer shops disagree with E-waste management strategy (EPR) because they think that it reduces their income and they don't think that it will be effective strategy because of money. They think that this program cannot buy back consumers' product in higher price than informal sector can.

- Nowadays, some producers in computer business sell or auction their obsolete computers and other parts which collect from their customer service centers to secondhand shops.

- Many secondhand shops sell used computers which import from other countries such as Japan.

- There are huge networks of secondhand computer importation which is very high cost business (some of secondhand computer trading is illegal in their countries).

\section{CONCLUSION AND RECOMMENDATIONS}

Thailand is not only face to large quantity of domestic Ewaste and improper E-waste management but also face to secondhand electronic equipment, discard electronic appliances that illegal imported from developed countries. Improper management of E-waste disposal by the informal sector with unsafe methods may cause hazardous substances contaminated to the environment lead to threatening human health.

To solve E-waste problems should consider the following points:

1) Improve knowledge and understanding about E-waste proper management and rising awareness of waste separation to Thai people especially to the informal sector.

2) Promulgate specific E-waste management law in order to have a proper treatment of E-waste and rising public awareness about E-waste issues.

3) Elucidate and promote the alternative role for the informal sector in proper E-waste management system. (emphasize on their paticipation)

4) Support the establishment of the good management complete system of E-waste separation, dismantling and recycling factories all over the country for easy access to all people.

5) Support private sector and informal sector to join take back system and invest to operate environmentally friendly dismantle and recycle factories.

6) Support local government to have effective waste collection and separation system including the fund to operate.

7) Improve law enforcement about proper E-waste management both monitoring and controlling.

\section{ACKNOWLEDGMENT}

The financial support from the TAIST-Tokyo Tech Program and Department of Common and Graduate Studies, Sirindhorn International Institute of Technology, Thammasat University are gratefully acknowledged.

\section{REFERENCES}

[1] Gagliardi D. MM. Overview of OSH issues related to the e-waste management. Geneva, Switzerland: World Health Organization.

[2] Collins T, Kuehr, R., Kandil, S., et al. World E-waste Map Reveals National Volumes, International Flows. StEP, United Nations University (UNU), Massachusettes Institute of Technology (MIT), National Center for Electronics Recycling (NCER), 2013.

[3] Diaz-Barriga F. Evidence-based intervention programs to reduce children's exposure to chemicals in e-waste sites. WHO working meeting on e-waste and children's health; 2014 Sept, 172013. p. 1-90.

[4] Wong CSC, Duzgoren-Aydin, N.S., Aydin, A., Wong, M.H.,. Evidence of excessive releases of metals from primitive e-waste processing in Guiyu, China. Environ Pollut. 2007a;148:62-72. http://dx.doi.org/10.1016/j.envpol.2006.11.006

[5] Frazzoli C, Orisakwe, O.E.,Dragone, R.,Mantovani, A.,. Diagnostic health risk assessment of electronic waste on the general population in developing countries scenarios. Environ Impact Assess Rev. 2010;30:388-99. http://dx.doi.org/10.1016/j.eiar.2009.12.004

[6] Zhang S, Forssberg, E.,. Mechanical separation-oriented characterization of electronic scrap. Resources, Conservation and Recycling. 1997;21:247-68. http://dx.doi.org/10.1016/S0921-3449(97)00039-6

[7] Duffert C, Brune, M.N., Prout, K. Background document on exposures to e-waste. Geneva, Switzerland: World Health Organization.

[8] Chan JKY, Wong, M.H. A review of environmental fate, body burdens, and human health risk assessment of PCDD/Fs at two typical electronic waste recycling sites in China. Sci Tot Environ. 2012;463-464:1111-23. http://dx.doi.org/10.1016/j.scitotenv.2012.07.098

[9] Puckett J, Byster, L., Westervelt, S., et ai. Exporting harm: the high-tech trashing of Asia. Basel Action Network. 2002

[10] Chen A, Dietrich, K.N., Huo. X., Ho, S. Developmental neurotoxicants in e-waste: an emerging health concern. Environ Health Perspect. 2010;119:431-8. http://dx.doi.org/10.1289/ehp.1002452

[11] PCD. Legislative Drafting on the Management of Waste Electrical and Electronic Equipment and Other Household Hazardous Wastes. Center of Excellence for Environmental and Hazardous Waste Management, Chulalongkorn University, 2014.

[12] Vassanadumrongdee, S. Electronic waste problems. Environmental Research Institute, Chulalongkorn University, 2015.

[13] PCD. Draft Report of Thailand pollution situation in 2015. Pollution Control Department, 2016. http://www.pcd.go.th/public/Publications/print_report.cfm

[14] PCD. Integreatd WEEE management Strategy in 2014-2021. Waste and Hazardous Substances Management Bureau, Pollution Control Department, 2015.

Sirada Pookkasorn was born on November 14, 1990, in Bangkok, Thailand. Her educational background was a Bachelor's Degree in Environmental Science program from Thammasat University, Thailand in 2013.

Now, She is studying TAIST-Tokyo Tech (Thailand Advanced Institute of Science and Technology), Master's degree international program in "Advanced and Sustainable Environmental Engineering" under the collaborative program of National Science and Technology Development Agency (NSTDA), Tokyo Institute of Technology (Japan), and Sirindhorn International Institute of Technology (SIIT).

Assoc.Prof.Dr.Alice Sharp, her advisor in this study, She is the Advisor of School of Bio-Chemical Engineering and Technology (BCET) at Sirindhorn International Institute of Technology, Thammasat University, Thailand. 